\title{
Development of biologized system of protection of garden strawberry against dominant berry rot in the conditions of Western Ciscaucasia
}

\author{
Yulia Kashchits ${ }^{*}$, and Galina Yakuba \\ Federal State Budget Scientific Institution «North Caucasian Federal Scientific Center of \\ Horticulture, Viticulture, Wine-making», str. 40 Let Pobedy, 39, 350901 Krasnodar, Russia
}

\begin{abstract}
In connection with an increase in the harmfulness of pathogens causing berry rot on strawberries, a high risk of developing resistance to chemical synthesis drugs and a long waiting period for these fungicides, research on the selection of microbiological means of protecting crops from the dominant pathogens of berry rot is relevant. The purpose of the research: assessment of the biological effectiveness against sulfur and berry's anthracnose rot of microbiological preparations and the development of regulations for their use in the conditions of the Western Ciscaucasia. The studies were carried out in 2019-2020 in the Krasnodar Territory on the Onda variety. The greatest biological effectiveness against the pathogen of gray rot was noted for the drug Fitosporin-M, Zh (with a consumption rate of $2.01 / \mathrm{ha})-81.2 \%$. Slightly lower efficiency was obtained for Alirin-B, Zh (40 1/ ha) and Alirin-B, SP (40 g / ha): 75.4 and $70.0 \%$, respectively. Fitosporin-M, Zh (2.0 1/ ha) and Alirin-B, SP (40 g / ha), respectively, showed high biological effectiveness against the causative agent of anthracnose rot -86.1 and $81.9 \%$. The elements of a biologized technology for protecting garden strawberries from these pathogens are recommended, which allow maximizing the yield, improving the quality of products by increasing its environmental safety, and preventing a decrease in the sensitivity of B. cinerea and C. acutatu to chemical fungicides. Highly effective reduction of the infectious stock in the period after flowering and before harvesting, inclusive, allows in the second half of the growing season to reduce the number of treatments by 1 2 , thereby reducing energy consumption.
\end{abstract}

\section{Introduction}

One of the most cultivated berry crops in horticulture is Fragaria $\mathrm{x}$ ananassa Duch. One of the most dangerous phytopathogens in the southern region for garden strawberries are pathogens of gray rot, Botrytis cinerea Pers., And anthracnose rot of berries, Colletotrichum acutatum Simmonds. Without the use of means of protection, product losses from these pathogens can reach $80-90 \%[1,2]$. The previously developed systems of protective measures on garden strawberries, aimed at combating berry mycoses, were based on the use

\footnotetext{
* Corresponding author: kashitz2012@yandex.ru
} 
of chemicals that pose a serious threat to the environment [2]. With the unilateral use of pesticides of chemical synthesis, the natural mechanisms of self-regulation of biocenoses are disrupted and resistance to these drugs in harmful organisms occurs [3]. According to Suty et al., The pathogen of gray rot has a high degree of development of resistance to the chemicals used [4]. Likhachev found resistance to 36 fungicides in B. cinerea, and the population of resistant isolates to dicarboximide in percentage was $44 \%$ [5]. There is very little information about the use of microbiological preparations on garden strawberries. Schoonbeek et al. the resistance of B. cinerea to antibiotics synthesized by the beneficial bacterium Pseudomonas fluoresce ${ }^{\mathrm{TM}}$ has been shown [6]. In the studies of I.A.Undritsova, the drug Alirin-B, SP, with a consumption rate of $0.06 \mathrm{~g} / \mathrm{ha}$, did not show a significant effect when applied during the flowering period, however, high efficiency was noted when applied after standard preparations used to protect strawberries from rot. Also, the researcher notes the high efficiency of the drug Pharmayod [7].

Against the causative agent of anthracnose rot, according to the results of Ellis, in Ohio, when processing strawberries during the flowering period, the best protection of berries was achieved when using the active ingredients metiram, + pyraclostrobin, captan and fludioxynil + cyprodinil. Benomyl and kresoxim-methyl turned out to be less effective [8, 9]. In the UK, the drugs Captan, SP and Switch, VDG showed good results, and the drugs Topsin-M, CE, Copper, Zh, Sulfur, VDG, Show jumping, CE, Rovral, SP, Ridomil Gold, VDG, Aliett, SP could not contain the spread anthracnose rot [10]. According to the literature, no biological agents have been identified against anthracnose of garden strawberry that can inhibit its development.

In addition, an extremely limited list of drugs allowed for use on garden strawberries on the territory of the Russian Federation should be noted: microbiological - Baksis, Zh, Alirin-B, Zh, Rizoplan, Zh, Glyokladin, Zh and chemical Luna Tranquility, KS. Therefore, the search for promising drugs that inhibit the development of pathogens of gray and anthracnose rot of berries is relevant.

The purpose of our study was to assess the biological effectiveness of microbiological preparations against pathogens of gray and anthracnose rot of garden strawberries and to develop regulations for the use of drugs in the conditions of the Western Ciscaucasia.

\section{Materials and methods}

The studies were carried out in 2019-2020. on industrial plantations of garden strawberries, Krasnodar Territory, Krasnodar, varieties Onda. The objects of the study were microbiological preparations Alirin-B, Zh; Alirin-B, SP; Baktofit SP; Fitosporin-M, J. The chemical fungicide Luna Tranquility, KS (125 g / L fluapiram + $375 \mathrm{~g} /$ L pyrimethanil), registered for use in culture, served as the standard.

All tested microbiological preparations are developed on the basis of the bacterium Bacillus subtilis. Baktofit, SP - strain IPM 215 (BA-10,000 U / g, titer at least 2 billion spores $/ \mathrm{g}$ ). The biological activity of the drug is determined by both the antagonism of the culture itself and the antibiotic synthesized during growth and belonging to the aminoglycoside group [11]. Alirin-B, Zh, SP - strain 10-VIZR (for the liquid form the titer is not less than $109 \mathrm{CFU} / \mathrm{ml}$, for the wettable powder the titer is not less than $1011 \mathrm{CFU} /$ g). Mechanism of action: the drug increases the content of protein and ascorbic acid by 20 $30 \%$ in plants [12]. Fitosporin-M, Zh - strain $26 \mathrm{D}$ (titer of at least 1 billion live cells and spores / ml). The mechanism of action of the drug is based on the suppression of a live spore culture of pathogenic fungi and bacteria by the products of their vital activity [13].

The experiments were carried out according to the method of B.A. Dospekhova [14]. The drugs were used 4 times, in 4 times. The first treatment was carried out in the "beginning of flowering" phase of garden strawberries, the subsequent ones - with an 
interval of 7-10 days. The location of the plots is randomized, the size of one plot is $10 \mathrm{~m}$. The scheme of the experiment is presented in Table 1.

Table 1. Scheme of the experiment to determine the biological effectiveness of fungicides on garden strawberries against pathogens of berry rot, variety Onda

\begin{tabular}{|c|c|c|}
\hline Fungicide name & Consumption rate, ha & Multiplicity \\
\hline Alirin-B, Zh & $4.0 \mathrm{~L}$ & 4 \\
\hline Baktofit, SP & $0.8 \mathrm{KG}$ & 4 \\
\hline Fitosporin-M, Zh & 2.01 & 4 \\
\hline Alirin-B, SP & $40.0 \mathrm{~g}$ & 4 \\
\hline Luna Tranquillity, KS (standard) & 1,01 & 1 \\
\hline The control & without processing & - \\
\hline
\end{tabular}

Weather conditions during the years of research were distinguished by the following features (Fig. 1, 2).

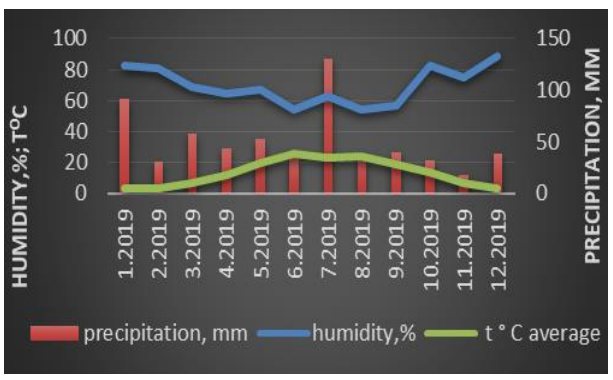

Fig. 1. Weather conditions in Krasnodar during the growing season in 2019

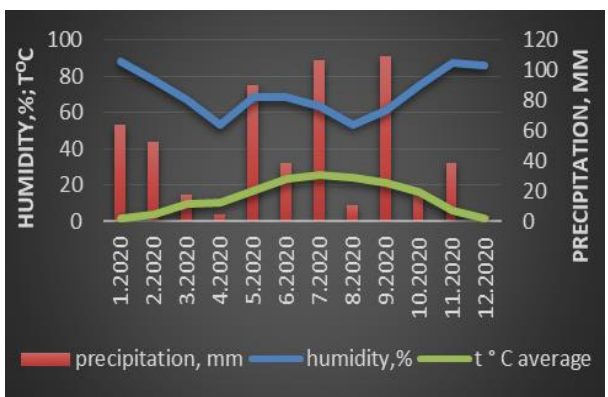

Fig. 2. Weather conditions in Krasnodar during the growing season in 2020

In 2019, the air temperature was below normal in April in the 1 st decade by $0.3^{\circ} \mathrm{C}$, there was a decrease to $-1.2^{\circ} \mathrm{C}$; in April in the 2 nd decade below the norm by $0.9^{\circ} \mathrm{C}$. The temperature was higher than normal in April in the 3 rd decade by $1.5^{\circ} \mathrm{C}$; in May in the $1 \mathrm{st}$ decade by $2.0^{\circ} \mathrm{C}$, in the 2 nd decade by $2.0^{\circ} \mathrm{C}$, in the 3 rd decade by $2.7^{\circ} \mathrm{C}$; in June in the 1st decade by $5.6^{\circ} \mathrm{C}$, in the 2 nd decade by $6.0^{\circ} \mathrm{C}$, in the $3 \mathrm{rd}$ decade by $4.8^{\circ} \mathrm{C}$. Precipitation was above the norm in March in the 1 st decade (264\% of the norm) in the 2nd decade (293\%), in the 3rd decade (121\%); in April in the 2nd decade (108\%); in May in the 1 st decade (169\%); in June in the 3rd decade (161\%). 
In 2020, the temperature was below normal in April in the 1 st decade by $2.3^{\circ} \mathrm{C}$, in the 2nd decade by $0.9^{\circ} \mathrm{C}$, in the 3rd decade by $0.9^{\circ} \mathrm{C}$; in May in the 3 rd decade by $1.8^{\circ} \mathrm{C}$. The temperature was above normal in March in the 1 st decade by $3.3^{\circ} \mathrm{C}$, in the 2 nd decade by $2.0^{\circ} \mathrm{C}$, in the $3 \mathrm{rd}$ decade by $9.1^{\circ} \mathrm{C}$; in June in the 1 st decade by $1.2^{\circ} \mathrm{C}$, in the 2 nd decade by $2.3^{\circ} \mathrm{C}$, in the 3rd decade by $2.8^{\circ} \mathrm{C}$. Precipitation was below normal in March in the 1 st decade ( $48 \%$ of the norm), in the 2 nd decade $(31 \%)$, in the 3rd decade $(46 \%)$, in April in the 2nd decade (18\%), in the 3rd decade (2\%); June in the 3rd decade (3\%). Precipitation was above the norm in May in the 1st decade (149\%); in May in the 3rd decade $(212 \%)$, in June in the 2nd decade (118\%).

\section{Results and discussion}

Under the conditions of 2019, the first manifestation of gray rot on strawberries was noted on May 21, during the "main harvest" phase. In the seasonal dynamics of the disease, its maximum development was recorded twice - during the harvest period: on May 28, in the "main harvest" phase, in the presence of a relative humidity in the range of $62-77 \%$ and an average air temperature of $20^{\circ} \mathrm{C}$, the intensity of development was $21.3 \%$; On June 6 , in the "second harvest" phase, after increasing the relative humidity to $63-78 \%$ for four days, the intensity of development was $42.1 \%$. In 2020, gray rot on berries was detected on May 23 , in the "onset of ripeness" phase. The maximum development of the disease was also noted in two periods - during the ripening of berries: on May 25, in the phase of "the beginning of berry ripeness" and on May 28, in the phase of "main harvest", when the air temperature was in the range of $18.5-23.5^{\circ} \mathrm{C}$, and the humidity is 77 and $88 \%$. Development intensity indicators reached 11.3 and $15.2 \%$, respectively.

The first manifestation of anthracnose rot in 2019 was recorded on May 3, in the "full bloom" phase of garden strawberries. In the range of daily temperatures of $15.0-32.5{ }^{\circ} \mathrm{C}$ and in the presence of a humidity of $70-87 \%$, the incubation period for the fungus $\mathrm{C}$. acutatum lasted from 4 to 8 days, which is important for establishing the intervals between spraying. The intensity of the development of the disease reached $88.5 \%$. In 2020 , the first manifestation of the symptoms of the disease was established on May 20, in the "beginning of berry ripening" phase, with the sum of effective temperatures $70.5^{\circ} \mathrm{C}$ and humidity 82 $77 \%$. The maximum intensity of the development of the disease coincided with the phase of "basic collection" and amounted to $17.6 \%$.

As a result of tests, the best efficacy against the pathogen of gray rot was noted in the preparations Fitosporin-M, Zh (2.0 l / ha) and Alirin-B, Zh (40 l / ha), which corresponds to the effectiveness of the fungicide of chemical origin - Luna Tranquility, KS. Insufficient biological effectiveness was noted for the preparations Alirin-B, SP (40 g/ ha) and Baktofit, SP $(0.8 \mathrm{~kg} / \mathrm{ha})$ : by 5.9 and $8.2 \%$, respectively, lower than the effectiveness of the standard (Figure 3), which is an insignificant difference.



Fig. 3. Biological effectiveness of drugs against the causative agent of gray berry rot, variety Onda, Krasnodar 


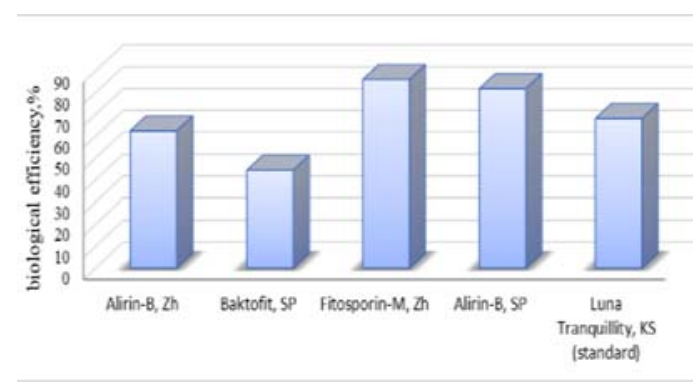

Fig. 4. Biological effectiveness of fungicides against the causative agent of anthracnose rot of berries, variety Onda, Krasnodar

Against the causative agent of anthracnose rot, with the development of the disease in the control of $17.6 \%$, the best biological effectiveness was shown by the preparations Fitosporin-M, Zh (2.0 l / ha) and Alirin-B, SP (40 g / ha): respectively by 26, 2 and 20.0\% higher than the efficiency of the standard version. The biological effectiveness of the drug Baktofit, SP was $34.8 \%$ lower than the effectiveness of the standard variant.

The results obtained will be used in the development of technology elements for protecting garden strawberries from gray and anthracnose rot of berries. Recommendations for the use of drugs against gray and anthracnose rot of berries have been developed: according to the phases of culture development and depending on the timing of the first manifestation and the maximum development of diseases. In the "flowering" phase, the chemical fungicide Luna Tranquility, KS is used once with a consumption rate of 0.8-1.2 1/ ha. After flowering, when chemical synthesis preparations cannot be used due to long waiting times, microbiological fungicides are used. At the end of flowering, with an interval of 5-7 days, two successive treatments are carried out with Alirin - B, F with a consumption rate of $4.01 /$ ha. In the "beginning of berry ripening" phase, garden strawberries are treated twice with Fitosporin-M, F with a rate of $2.01 /$ ha with an interval of 7-10 days, or twice with Alirin-B, SP with a rate of $40.0 \mathrm{~g} /$ ha with the same interval ... It is possible to use the alternation of these drugs, which depends on the strength of the development of each of the diseases. In the phase "main collection", depending on the duration of the harvesting period, Fitosporin-M, F with a rate of $2.01 /$ ha and Alirin - B, F with a rate of $40.01 /$ ha are used once or twice. The interval between treatments is $7-8$ days.

\section{Conclusion}

New experimental data have been obtained on the effect of microbiological fungicides on the causative agents of gray and anthracnose rot of garden strawberries - B. cinerea and C. acutatum. The elements of a biologized technology for protecting garden strawberries on the Onda variety from these pathogens are recommended for the conditions of the Western Ciscaucasia. The proposed preparations allow obtaining a number of environmental and economic effects. First of all, to preserve the harvest as much as possible and improve the quality of products by increasing its environmental safety, reduce the pesticide pressure on the environment, and also prevent a decrease in the sensitivity of pathogens to chemical fungicides. Highly effective reduction of the infectious stock of B. cinerea and C. acutatum in the period after flowering and before harvesting inclusively due to the possibility of using microbiological preparations allows in the second half of the growing season to reduce the number of treatments against gray and anthracnose rot on leaves by 1-2 and thereby reduce energy consumption when cultivating garden strawberries. 


\section{References}

1. N.A. Kholod Plant Protection, 10, 28 (2013)

2. Yu.P. Kashchits, Bulletin of the State Nikitsky Botanical Garden, 137, 23 (2020)

3. V.A. Chulkina, V.I. Usenko, Phytosanitary optimization of agroecosystems of fruit and berry crops, 240 (2015)

4. A. Suty, R. Pontzen, K. Stenzel. Pflanzenschutz-Nachrichten Bayer, 52, 145 (1999)

5. A.I. Likhachev, Mycology and phytopathology, 25(3), 240 (1991)

6. H. Schoonbeek, J. Raaijmakers, M. De Waard. Molecular Plant-Microbe Interaction. 15(11), 1165 (2002)

7. I.A. Undritsova, State and prospects for the development of berry growing in Russia, 300 (2006)

8. M. Ellis, Using fungicides to control strawberry fruit rots in Ohio. Department of Plant Pathology, the Ohio State University, OARDC, 5 (2004)

9. S. Ivanović, B. Duduk, M. Ivanović, S. Ivanović. Collection Matice Srpske for Natural Sciences, 113, 74 (2007)

10. J Barbara, Smith, A North American Perspective HortScience, 43(1), 69 (2008)

11. Network edition AgroXXI.ru, https: //www.agroxxi.ru

12. Directory Pesticides.ru, https: //www.pesticidy.ru

13. Directory Pesticides.ru, https: //www.pesticidy.ru

14. B.A. Dospekhov, Field experiment technique, 352 (2014) 